\title{
Narrative strategies in the origin of journalism: An analysis of the first Spanish-language gazettes
}

\author{
Javier Díaz Noci \\ Universitat Pompeu Fabra \\ javier.diaz@upf.edu
}

\author{
Submission date: March 2017 \\ Accepted date: April 2017 \\ Published in: June 2017
}

Recommended citation: DÍAZ NOCI, J. (2017). «Narrative strategies in the origin of journalism: An analysis of the first Spanish-language gazettes». Anàlisi. Quaderns de Comunicació i Cultura, 56, 15-31. DOI: <http://dx.doi.org/10.5565/rev/analisi.3089>

\begin{abstract}
The topic of our study is journalism as a narrative genre. Before becoming periodical, newssheets adopted many forms at the end of the sixteenth and throughout the seventeenth centuries, which we aim to typologize before conducting a corpus-based analysis (Biber, 2009, 2012), in which pre-determined categories will be applied in search of patterns. In order to prove the validity and productivity of this approach in an exploratory manner, we have applied those methods to a reduced corpus of some of the first gazettetype printed newssheets in the Spanish language, so as to longitudinally extend this strategy in further research to many other corpora of miscellaneous newssheets. This first tentative sample is composed of four newssheets published from 1597 to 1621, our goal being to trace the patterns and continuities of a narratological model for the early days of Spanish journalism. In our opinion, and following an Italian style detailed by Panfilo Persico in Il Segretario (Venice, 1620), narrative newswriting strategies, at least in the Mediterranean area, were most especially consolidated during the Thirty Years War (1618-1648), and were even present in Spanish gazettes in one of the most flourishing periods of activity, the decade of 1683, because of the Turkish Wars (Díaz Noci, 2008).
\end{abstract}

Keywords: Early Modern journalism; communication history; narratology; newswriting

Resum. Estratègies narratives en l'origen del periodisme: una anàlisi de les primeres gasetes en llengua espanyola

El periodisme com a gènere narratiu és el tema d'aquest article. Abans d'esdevenir periòdics, els fulls de notícies adoptaren diverses formes entre finals del segle XVI i principis del XVII, de les quals tractem de fer una tipologia abans de procedir a una anàlisis basada en el corpus (Biber, 2009, 2012), en la qual es poden aplicar categories predeterminades per cercar patrons. Per provar la validesa i productivitat d'aquesta aproximació de manera 
exploratòria, hem aplicat diversos mètodes a un corpus reduït d'algunes de les primeres gasetes impreses en llengua castellana que es pugui estendre properament a altres corpora de fulls de notícies miscel.lanis o gasetes. Aquesta primera mostra temptativa es compon de quatre fulls de notícies tipus gaseta publicats entre 1597 i 1621 . El nostre propòsit és comprovar els patrons i les continuïtats d'un model narratològic aplicat als primers temps del periodisme espanyol. Segons el nostre parer i seguint un estil italià explicat per Panfilo Persico a la seva obra Il segretario (Venècia, 1620), les estratègies narratives de redacció periodística, almenys a l'àrea mediterrània, es van consolidar molt especialment durant la guerra dels Trenta Anys (1618-1648) i són encara presents fins i tot en un dels períodes més fructífers d'activitat de producció informativa a Espanya, la dècada de 1680, a causa de la guerra contra els turcs (Díaz Noci, 2008).

Paraules clau: periodisme; història moderna; història de la comunicació; narratologia; redacció periodística

Resumen. Estrategias narrativas en el origen del periodismo: un análisis de las primeras gacetas en lengua española

El periodismo como género narrativo es el tema de este artículo. Antes de convertirse en periódicos, las hojas de noticias adoptaron diversas formas entre finales del siglo XVI y principios del XVII, de las cuales tratamos de ofrecer una tipología antes de proceder a un análisis basado en corpus (Biber, 2009, 2012), en el que se pueden aplicar categorías predeterminadas para buscar patrones. Para probar la validez y la productividad de esta aproximación de manera exploratoria, hemos aplicado diversos métodos a un corpus reducido de algunas de las primeras gacetas impresas en lengua castellana que se puedan extender próximamente a otros corpus de hojas de noticias misceláneas o gacetas. Esta primera muestra tentativa se compone de cuatro hojas de noticias tipo gaceta publicadas entre 1597 y 1621 . Nuestro propósito es comprobar los patrones y la continuidad de un modelo narratológico aplicado a los primeros tiempos del periodismo espańol. Según nuestra opinión, y siguiendo un estilo italiano explicado por Panfilo Persico en su obra Il Segretario (Venecia, 1620), las estrategias narrativas de redacción periodística, al menos en el área mediterránea, se consolidaron muy especialmente durante la guerra de los Treinta Años (1618-1648) y todavía están presentes incluso en uno de los períodos de actividad de producción informativa más fructíferos en España, la década de 1680, debido a la guerra contra los turcos (Díaz Noci, 2008).

Palabras clave: periodismo; historia moderna; historia de la comunicación; narratología; redacción periodística

\section{Introduction}

The main characteristics of journalism were shaped around the time of the Thirty Years War, a period when the hunger for news and the consolidation of the printing press created a popular market for newssheets (see, for instance, Boys, 2012). The typology of those printed -and not unusually handwritten- products was varied. We propose a distinction between handwritten and printed newssheets, between individual and miscellaneous papers, and between isolated, serial and periodical (or even semi-periodical) sheets (Díaz Noci, 2016). Different products and names in the different languages and cultures of Europe have been examined by scholars (Chartier and 
Espejo, 2012; Expósito, 2014, Ettinghausen, 2015, Infelise, 2016; Groesen and Helmers, 2016): avvisi, coranti and gazzette in Italian, corantoes, newsbooks and gazettes in English, Neue Zeitungen in German, relaciones, nuevas, avisos and gazetas in Spanish - without claiming to be exhaustive. Some scholars have concentrated on the handwritten production of news in Italy (Mario Infelise is the major one), while others have defined the production of individual, even occasional, news in Europe (Ettinghausen, 2015). As a group named Ibemnews, we prefer to focus on what, in general terms, we call gazettes, meaning those newssheets, periodical or not (even serialized), composed of several news items, usually from different parts of the world. We assume, as a starting point, that such newssheets features a set of characteristics that distinguish them from the individual letter of news or relación de noticias (or de nuevas), composed of just one item that is covered in greater length. This has been studied for a later period by, for instance, Marcel Broersma and Martin Conboy (Broersma, 2007; Conboy, 2007 and 2010). The shape and contents of those news items, usually translated, adapted and mashed up from and to other languages, is the subject of this paper.

We employ here just one of the many methods that we intend to apply to this corpus of news items taken from an exhaustive list of miscellaneous newssheets or gacetas printed in the several kingdoms of Early Modern Spain or in the Spanish language abroad. For instance, there were some periodical gazettes published at the end of the seventeenth century in Brussels and Amsterdam (Díaz Noci, 2012). Due to the volume of the corpus, we intend to work with several smaller corpora. It is not our intention in this short paper to explain the constitution of those corpora, mention sufficing of the plan exposed in Baena et al., 2014; Díaz Noci, 2016, and, more specifically and as a model to be followed, Fries and Schneider, 2000, and Facchinetti et al., 2012.

Instead, in this paper we merely present a sample of one of those corpora, the first in chronological order, composed of miscellaneous Spanish-language newssheets published before the Thirty Years War (1618-1648) or during its earliest years. Precisely, we have constructed a tentative sample, since we are aware of its limited representativeness with regard to the whole corpus, a work in progress, composed of some non-periodical (or even semi-periodical) miscellaneous newssheets that appeared between 1597 and 1621. We have left aside a highly interesting series of gazettes published between September 1618 and 1620 in Valencia by Felipe Mey, a collection of at least eleven newssheets containing items of Italian origin, with different titles but a similar configuration and published semi-periodically and discovered by Carmen Espejo and Francisco Baena, which will be analyzed in a later phase of our research project. As Carmen Espejo and Francisco Baena have made clear (Espejo and Baena, 2015), this can be even be considered the first continuous newspaper in Spain. Instead, the newssheets we analyze in this paper were not continuous as a series - even though the printers naturally did publish some other non-miscellaneous informative sheets during the period. In doing 
so, we seek to understand how the miscellaneous characteristic came first, and periodicity or, at least, continuity was proposed -or was possible- sometime later. Therefore, the printed sheets that we analyze in this article were the first pre-periodical gazettes in the Spanish language.

Those four miscellaneous newssheets were all published in one of the main informative foci of the Iberian Peninsula, Seville. These are Nuevos avisos venidos de Roma... (Rodrigo de Cabrera: Seville, 1597), Gazeta Romana (Seville, 1618), Relación de avisos de Roma, Flandes etc. (Seville, 1621), and Relación de las cosas del Imperio (Seville, 1621).

Our purpose, based on a report presented at the sixth international colloquium held by the SIERS (Sociedad Internacional para el Estudio de las Relaciones de Sucesos) in 2010 and completed since then, is to explain the narrative strategies of what would later be called commercial activity. This is not new, since, for instance, Jean-P. Guinard, 1973; in his case, for a later period, the eighteenth century, like Nevalainen, 2002, Koopmans, 2016, Nicholas Brownlees (see bibliography, different years), Stéphane Haffemayer and the team led by Jorge de Sousa have tried, from different perspectives, to investigate the several narrative strategies of the gazettes published in Spanish, English, French and Portuguese. Our modest but original contribution is to add another well-known and, in our opinion, productive technique to those that have previously been essayed qualitatively and quantitatively (especially, in this case, Haffemayer and Sousa et al.) by other scholars: narratology.

\section{On narratology applied to Early Modern journalism}

\subsection{Why apply narratology to Early Modern journalism?}

Narratology is a research method used to explain the structure and characteristics of any kind of narrative text or discourse (e.g., Adam, 1987; Adam and Revaz, 1996; Bal, 2009, Herman, Jahn and Ryan, 2005) that is extensively applied to fiction but far less to non-fictional texts. There have, however, been some attempts that are worthy of mention in this respect, e.g. Berning, 2011, and Díaz Noci, 2014, but for modern forms of news. Since narratology seeks to explain what story is told and how, it is a technique that seeks narrative patterns.

To analyze the journalistic style of the earliest examples of miscellaneous gazettes, we applied a highly comprehensive narratological template to explain the general trends observed in the construction of such stories. We then compared these with what could be considered the first, so to say (once again, the term is anachronistic), news stylebook, at least for the Italian and Mediterranean area: Panfilo Persico's Del segretario, published in Venice, which was a focus of news in Europe at the time around 1620. Since most of the news reproduced by the Spanish gazettes originated from Italy, it is not improbable that many of the Early Modern gazetteers of the Mediterranean world followed the same rules and recommendations. 


\subsection{Topics of news items}

The topics mainly related to two concerns: war and politics. Some other concerns were always present: religion (to be included in politics, since news on this topic reflected Papal involvement in the tumultuous panorama of Europe during the prelude to the Thirty Years War), disasters (actually, only one is mentioned in the newssheet of 1618, a tempest in Naples), and weddings, births and deaths among the nobility. Disasters were usually treated at greater length in occasional individual newssheets or relations (Ettinghausen, 2016), while the other topics reflect the typical thematization that would be fully incorporated by periodical newspapers to our days.

Table 1. Newssheet topics

\begin{tabular}{lccccccc}
\hline & Politics & War & Religion & Disasters & Travel & Weddings & Deaths \\
1597 & & All & & & & & \\
1618 & 3 & 8 & 6 & 1 & 8 & 2 & 1 \\
$1620-21$ & 1 & 1 & 3 & & & 1 \\
\hline
\end{tabular}

Source: The author.

Some of the news stories were of special importance, but narrated in a similarly short manner to all the other items. For instance, in 1621 (Relación de avisos de Roma etc.) the Pope's death and the election of a new one, Gregory V, was reported. Seville appeared in this news item, when the anonymous writer (who obviously arranged and added new information to the original letters from Rome) explained how the news about Paul V was received in the city.

\subsection{The origin of news}

Another preliminary matter is the origin of news, and the paths it took before arriving in Seville. This table reflects the dependence on two sources, and two postal methods, one terrestrial (from Central Europe, specifically from Flanders) and one maritime, from Italy:

Table 2. The geography of news

\begin{tabular}{|c|c|c|c|}
\hline Year & Origin & Via & Places mentioned \\
\hline 1597 & Italy & $\begin{array}{l}\text { Italy (Rome) } \\
\text { Flanders (Brussels, Liège) }\end{array}$ & $\begin{array}{l}\text { Italy (Rome, Turin), Flanders, } \\
\text { France, Netherlands, } \\
\text { Transylvania, Constantinople }\end{array}$ \\
\hline 1618 & Italy & $\begin{array}{l}\text { Italy, England, Poland, France, } \\
\text { Constantinople (via Ragusa), } \\
\text { Hungary (via Vienna) }\end{array}$ & $\begin{array}{l}\text { Italy, England, Poland, } \\
\text { France, Constantinople } \\
\text { Hungary, Denmark, Bohemia }\end{array}$ \\
\hline $1620-1621$ & Flanders (Brussels) & $\begin{array}{l}\text { Flanders, Spain, Hungary, } \\
\text { France, Flanders, Algeria } \\
\text { Brussels }\end{array}$ & $\begin{array}{l}\text { Italy (Rome, Sicily), France, } \\
\text { Hungary, Spain (Seville), } \\
\text { Algeria, England (London) }\end{array}$ \\
\hline
\end{tabular}

Source: The author. 
The places from where news items came most regularly included Italy, Brussels, London and Paris. Distant places, like Buda in Hungary, sent letters to the rest of Europe as well. However, information from Denmark and Constantinople, an interesting place since the Turkish court resided there and was a source of constant threat to the Continent, came indirectly, usually via Italy. In 1621, the Sevillian printers even tried to offer some information from their city as well, which was not a common practice at all (on how the Sevillian printers dealt with the Turkish Wars, see Espejo, 2015).

\subsection{Narrative strategies}

Regarding narrative strategies from a narratological point of view, the first newssheet examined, Nuevos avisos venidos de Roma en este mes de Octubre a sys dias del, was printed by Rodrigo de Cabrera in Seville in October 1597, and constitutes one of the first examples in the Iberian Peninsula of how news items could be gathered and packaged in just one four-page sheet to be sold to the public in one of the most populous cities of Spain, and a node of communication. The first thing to note is how the first page was conceived as a cover. Although there is no sign of engraving, which was quite common for individual, occasional newssheets composed by just one news item, the complete title was so long that it was designed to be a teaser for the reader, since it states clearly enough that it is a gazette and not just a single story about a single event. It is worth reproducing (we have modernized the spelling):

Nuevos avisos

Venidos de Roma en este mes de octubre a seis días de él. Y enviadas a diez del mes pasado de agosto de este ańo de noventa y siete, por el Licenciado Rodrigo de Olea de Ossinaga, al Padre Fray Alonso de Aguilar, de la Orden de Santo Domingo, a esta ciudad de Sevilla. en que se da cuenta de las cosas que pasan en Turquía. y del Príncipe Cardenal, en Francia y otras partes. Y de un presente que le envió el bearnés Vandoma, al dicho príncipe y el príncipe Cardenal a él un muy buen caballo. Hay aviso de cómo ha salido el gran Turco con ciento y veinte mil soldados. Impreso con licencia.

Certain narrative strategies are present in this teaser. First of all, there is an author (Diego de Olea de Ossinaga) and there is a receiver, a friar. It was a common strategy to make the veracity of the contents very clear, whereby they were attributed to a known informer who had sent a letter of news (carta de nuevas was a common title for such products before the gazette adopted its definitive form some decades later) to a specific person of some rank and, it is 
to be supposed, credibility. The author is, in this first newssheet, explicit. The cover previews, as a proemius, some of the contents of the booklet. This strategy, defined in our times as a teaser, was used by Juan Serrano de Vargas in 1618, in his Gazeta Romana, y relación general, de avisos de todos los reinos y provincias del mundo (once again, we modernize the spelling), a title in which he employs, significantly in our opinion, many of the terms used at that time to identify newssheets in Spanish: gazeta, relación and avisos. This seems to be the first, however, to decide to use gazeta as a name for such a printed production in Spain.

Figure 1. Relación de las cosas del imperio, by Francisco de Lyra (Seville, 1621). Front cover

\section{Bruffelas, a 30 . de Maio 621.}

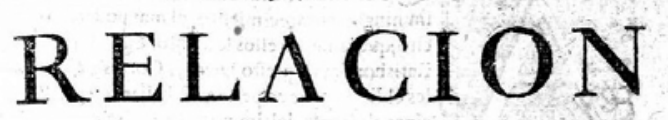

\section{DE LAS COSAS DEL}

INPERIO:

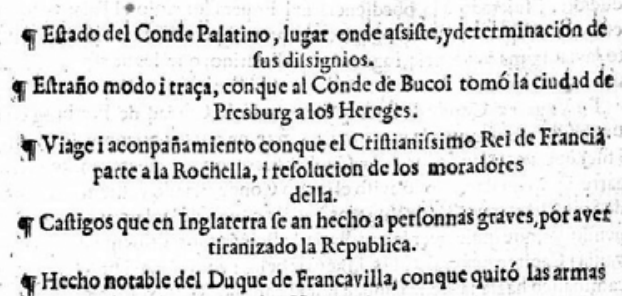
a los Hereges.

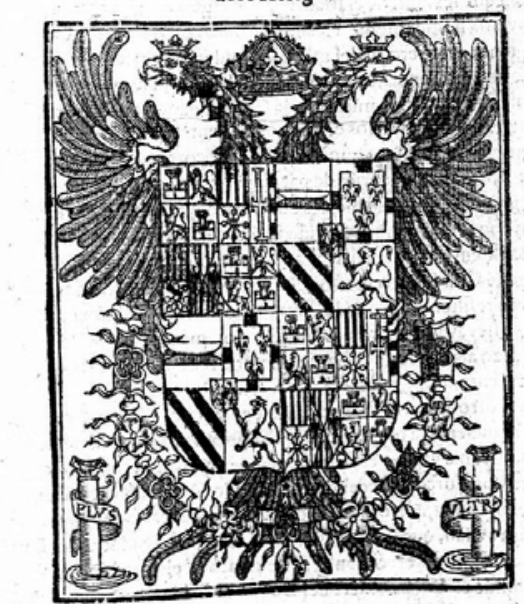

Con lieencia inpreffoen Sevilla, por Fradcifco de Lyra, en laetlle de la Muela. Ańo 16zis.

Source: Catálogo Colectivo del Patrimonio Bibliográfico, registro 000424138-X. 
This strategy was refined by the Sevillian printers, since in another newssheet of this small corpus, Francisco de Lyra in 1621, presents the several items to be developed in the inside pages on the front cover. To enforce the credibility of the stories, the compulsory (but not always respected) license is mentioned in both newssheets, and an engraving with the imperial arms seeks to gain some prestige. That same year, Juan Serrano de Vargas did the same in his Relación de avisos de Roma, Flandes, Sicilia, Alemania, Francia, Florencia y Argel, providing a list of five news items covered on the subsequent pages, and accompanying them with an engraving of the Papal coat of arms:

Figure 2. Relación de avisos de roma... by Juan Serrano de Vargas, Seville, 1621

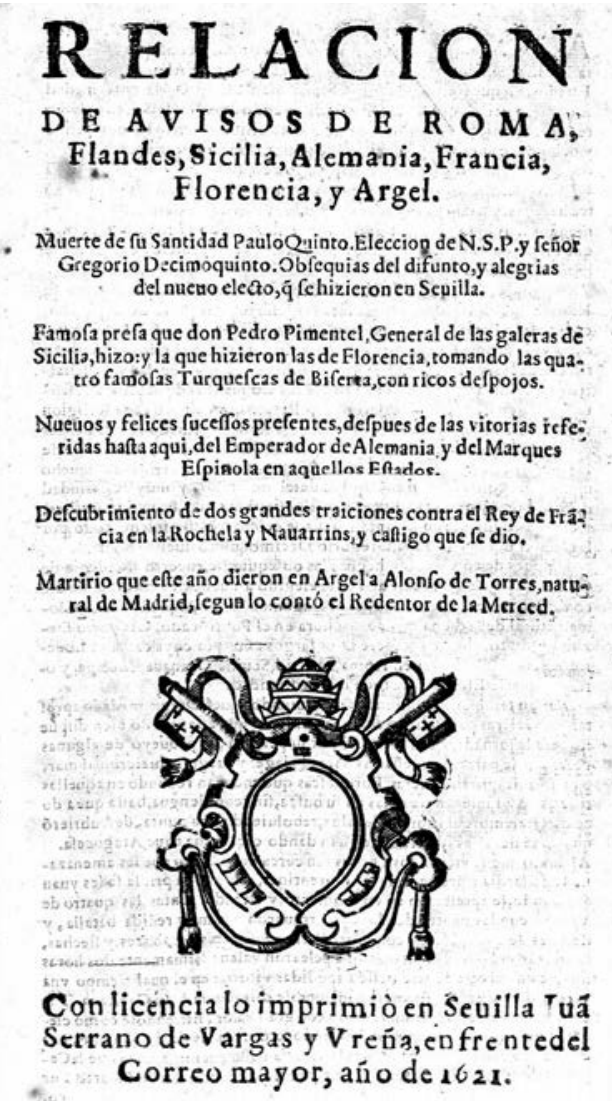

Source: Fondon Antiguo de la Universidad de Sevilla, A 109/085(022).

The specific narratologic analysis, summarized in the following table (table 3), shows the most common strategies of the incipient journalism of the time, stylistic regularities and alternations in the narrative strategies, which were common at a time of style formation. 


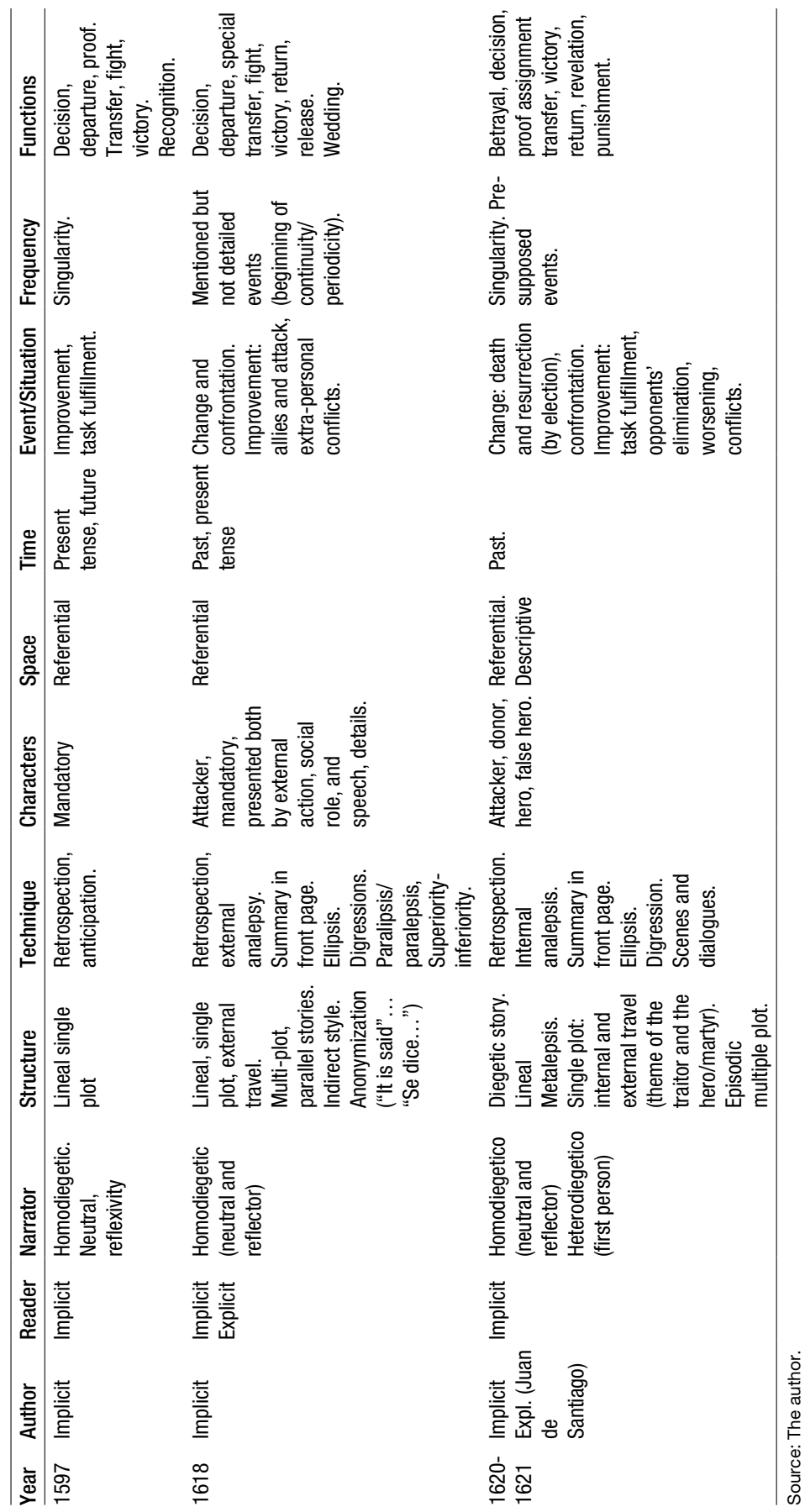




\subsubsection{Authorship and readership of news}

The author, usually implicit in news items, is however mentioned in two of the four newssheets we examine. It would be a trend in the style of miscellaneous gazettes from then onwards for the author to remain implicit or even anonymous. The Gazeta Romana mentions "a curious Sevillian knight" living in Rome as the correspondent of the letters on which the newssheet is based, but in all the others, as in many of the subsequent gazettes published in Spain, this is substituted by general mentions like "avísase de...", "por cartas llegadas de...", etc. When the printer and editor of the gazette is the person that is ultimately responsible for gathering several items of information from the post, and arranging, translating, abridging, or even completing them with other news of different origin, such formulas were preferred, at the expense of the credibility provided by the personal attribution to someone.

The reader, meanwhile, is usually implicit, but is mentioned in the newssheet of 1618. There is a tendency, however, for news items to be presented in a neutral, indirect way, in which neither the author nor the reader explicitly appears in the text. A significant exception, and prelude of the archetypical news story narrative strategy, is the direct (or semi-direct) narration used in 1621 by Juan Serrano de Vargas. After presenting the author of the story, a Sevillian priest named Juan de Santiago who returned from Algeria after trying to release some Spanish captives on commission by the Crown, voice is given to De Santiago, who tells how one of those captives, Alonso de Torres, heard a Moor of Spanish origin blaspheming against Catholicism, so he insulted the Muslin in his turn, and was martyred for this reason. The story precisely identifies both characters:

[...] yendo Alonso de Torquemada (cautivo, natural de Madrid) por una calle de Argel, con otro cautivo, le dijo un morisco (mesonero que fue en Valladolid, llamado Juan de Padilla, y en Argel, Mahomat Hazenumeya) cristiano, no se me da un ochavo de tu ley. A que respondió Torres: perro, traidor, morisquillo, yo me ensucio en tu Mahoma, y en todos sus preceptos y enredos, y en cuantos le creen y siguen (Relación de avisos de Roma etc., 1621).

\subsubsection{Type of narrations}

The narration is extradiegetic, but some items present intradiegetic (homodiegetic) narrators as well. A neutrally omniscient style was established as early as 1597, as well as some reflexivity. Other interesting resources were also used. Rodrigo de Cabrera published his Nuevos avisos venidos de Roma and the second news items used a reflector ("Los mercaderes de esta ciudad flamencos, tienen aviso de Bruselas..."). This was a very common narrative strategy: in 1618, a homodiegetic neutral-reflector narrator schema was tried. A Spanish captain, who was held captive in Constantinople, was used to explain the story of how some Christian captives had fled the Turks after burning the palace and the mosque. 
The stories tended to be lineal and single-plotted. A journey abroad is referred to in 1618, and both domestic and foreign trips are described in 1621 in a more elaborate manner, using the traitor and the hero (martyr, in this case) schema. Multiple episodic plots and parallel stories were used in this newssheet as well when reporting on the Pope's death, how the news was received in Seville and the reactions it caused, and the election of a new Pope in Rome.

Narrative techniques are richer within the archetypical structures that we have examined to this point. Ellipse, external analepsy (within the time lapse), paralepsis (contrasting superiority and inferiority) and digressive pauses were used in 1618 and in 1621, so much so that we maintain that they were a characteristic of style. A scene construction was even used in 1621 . Comparisons and other rhetorical figures were not unusual, for instance "salió tan atemorizado, que temblaba como si tuviera cuartanas" neither was irony: "Monsieur de Aidiguiera acompaña al Rey a do quiera que va [...]. Los hugonotes, por modo de burla, le llaman el oso de la Corte, y dicen, que el rey le trae consigo atado con una cadena, para amedrentar a los niños"; "Mr Adiguiera accompanies the King wherever he goes [...]. Huguenots, mocking him, calls him the Courts' bear, and they say that the King brings him tied with a chain, to intimidate children". Enumerations were quite frequent ("árboles, remos, entenas, y otras cosas", 1621). The influence of the religious, biblical style is evident, e.g. in the aforementioned story referring to a priest, Juan de Santiago, in 1621, exemplifying the martyrdom of a Spanish captive, which can be conceptualized as a parable with moral purposes, but using the narrative strategies of a news story.

\subsubsection{Characters of news narrations}

The characters were fairly archetypical in early journalism, as they are now, with a predominance of mandatory executives (noblemen, religious military and secular heads), and also of attackers (particularly Turks, the main enemy throughout the century). Other stories presented donors and (false) heroes in 1621. The characters were usually introduced by external actions or social roles (which was absolutely predominant in 1618), but in 1621, Juan Serrano de Vargas used an introduction by speech three times, this being a new resource to be added to the newly formed journalistic style. The events and situations were quite archetypical: task fulfillment and improvement $(1597,1618,1621)$, especially when describing military campaigns. Elections and confrontations were typical as well, along with the elimination and punishment of opponents (the English king decided to execute a traitor in 1621). Functions were related to those characters' roles: decision, departure, proof, fight, recognition and transfer appeared in all four newssheets consulted (thus introducing clear regularity) and, in 1621, a richer panorama included, along with the same categories of the preceding years, betrayal, revelation, punishment and return. Disguise was also used: "Vinieron doscientos hombres disfrazados en diferentes trajes", as appeared in 1621 (Relación de avisos de Roma...). 


\subsubsection{Space}

Space was referential from the very beginning, i.e. in 1597. Time combines present tense and recent past. The usual tendency in modern times -at least, in Latin languages- of explaining past events using the present tense was essayed in the early years of journalism (see, for instance, Francisco de Lyra in 1621 ("Sólo el Palatinato no está de todo punto reducido", "Only the Palatinate is not completely subdued"; "van prendiendo a muchos...", "they are capturing so many people..."), but the delay between the moment things happened and the time they came to be known made this difficult. Time strategies were conditioned by the days, weeks or even months that it took for a news story to get from its origin to the place where it was to be published, so editors and printers used several strategies. In this example, taken from the first newssheet we examine (that of 1597), it took several months for the story to reach the audience in Seville. The item was known in Rome to Flemish merchants living there from a news letter dated June 12, 1597: the Cardinal had taken two ships from the Netherlands that had gone to France an undetermined number of days (or weeks) before. That news item, along with several more, was sent from Rome to Seville by Rodrigo de Olea on 10 August 1597, edited on October 6 of that year and finally published two days later. Another news item, about an event that happened on 20 July 1597, was written in Genoa, July 25, and edited and published in Seville on October 6-8 that year. Although those dates were detailed in the stories in 1597 , such practices were less common in the following years. It is possible, however, to know when the different stories were written and thus adopted their primitive form in Italy and then were sent to Seville. These are the stories which appear in the second newssheet, that of 1618, after being received in a letter on June 11, 1618: the six news stories that made up the gazette were sent from Vienna on April 4, from Naples on April 22 and May 8, from Genoa on April 23, from Rome on April 26 and from Messina on April 30. It therefore took from one to two months for the stories to reach Seville. Two months was the normal period of time for making a news item known in those days, since the two newssheets of 1621 that we examine in this paper reflected a similar gap. So it is not surprising that retrospection was the main resource, whilst anticipation (with just one example, to announce what was expected to happen fifteen days after the newssheet had been published, by Francisco de Lyra in 1621) and in media res were not used.

\subsubsection{Frequency}

Frequency was difficult for the reasons explained above. Singularity was the rule: events happen once and are explained once. Nevertheless, it was tried, for instance in the newssheet of 1618, where some events are mentioned but not explicitly narrated, since it was supposed that the readers already knew about them. It is difficult to know how this was achieved, but many more newssheets were probably published than the few that have survived to the 
present day. Professor Henry Ettinghausen estimates that the newssheet survival rate is low: the fact that many of them are known because a single edition is extant (60\% in the Spanish case; Ettinghausen, 2015: 24) is sufficient proof of how most such printed pamphlets are now lost. This resource is especially important, since it tells us how periodicity was important as early as 1618, precisely when the Thirty Years War broke out. Somehow, readers were regularly informed about the evolution of the war and political events in Europe, so it was not absolutely necessary for the narrator to explain some events that were mentioned but not expanded upon in the story.

\section{Conclusion (and further research)}

There is much research to be done until the formation of a journalistic style in Spanish can be completely explained. While it is clear that both stylistic and thematic recurrence can be identified, such as that described from a narratological point of view, many variations helped to create a recognizable style in our days. More longitudinal research is needed, whereby we can incorporate more nourished corpora (see Oliveira Teixeira, 2013). We are aware of the limitations of this study, especially regarding the representativeness of a larger corpus, which is obvious. This paper should be conceived as a test of the potentialities of a narratological analysis applied to Early Modern journalism, even in combination with other techniques.

We also have to consider that there was not necessarily any equivalence between the place of publication and the languages used. To cite just a few examples: Spanish language gazettes were published in Brussels (Pedro de Cleyn) and in Amsterdam, in the latter case by a Jew of Portuguese origin, David de Castro Tartas, who simultaneously published periodical newspapers in Spanish (Gazeta de Amsterdam), Italian (Gazzetta d'Amsterdam) ${ }^{1}$ and Yiddish (see Díaz Noci, 2012), in the final quarter of the seventeenth century. Fifty years before, a Catalan printer, Esteve Liberós, published newssheets in Italian, not to mention the interesting though irregular production of newssheets in Catalan at different moments of the century (singularly, during the so-called Reapers' War or, as it is better known in the English-speaking world, the Catalan Revolt of 1640, see Ettinghausen, 1993).

We must stress the importance of the Italian models, one of the main places of origin of the news reproduced in the first Spanish gazettes. The first was Panfilo Persico. His aforementioned work, Del segretario, was published in one of the main news foci of Europe at that time, Venice, in 1620, and was printed continuously until the end of the seventeenth century. One section was devoted to newswriting, specifically the second chapter of the fourth book, titled Delle lettere d'aviso ("About newsletters"). It is interesting to examine

1. When closing this paper, we have come to know that there is an issue of this quite rare gazette extant in the Emeroteca Tucci, Naples (Italy), dated April 19, 1674. We thank very much the help provided by the people in charge of the library. 
Persico's recommendations or rules and compare them to the strategies that we have described above.

First of all, Persico distinguished between the writing of private or public news. The private news trade was highly developed, as Mario Infelise has masterfully described (see bibliography). The communication of public news was fairly established in the late sixteenth century (Rospocher, 2012; Olivari, 2014), and printers all over Europe sought to settle these new practices when the Thirty Years War broke out. While private letters were addressed to important people ("ministers", says Persico) the printing press allowed more common people to also feel like ministers. News from the courts ("descrittione delle cose che succedono nelle corti, e paesi dove risdedono") was thus predominant (the purpose of the avvisi delle nuove was, precisely, "avisar tuttociò, che succede nelle Corti"). Ambassadors (see Brownlees, 2012), secretaries and newsmongers around them were a source of news in Europe. Individual newssheets, called lettere di relatione by Panfilo Persico, were reserved for other events, like natural disasters. One of the rapidly adopted strategies recommended by Persico for the aviso d'historia, or news story, was to explain things in a simple way ("con semplicità"), mentioning, when necessary, the main characters' own words, and describing both actions and speech. To some extent, this was slightly attempted in the first Spanish gazettes that we examine. The purpose was clear: "esprimere, rappresentar, e narrare" ("explain, represent and tell") in some detail and in a clear, meaningful, well-ordered ("chiara, significante, ordinata") manner, principally considering characters and circumstances ("ogni individuo, \& ogni circonstanza"). This was reflected in narrative strategies: narration is usually indirect, neutral and confined to objective descriptions. In these news stories, "the virtue of storytelling is convenient" ("le convengono le virtú della narratione"). This excluded certain other strategies, like the in media res story: "Ce non si venga à narrar prima quel che andava nel mezzo, ò nel fin, e di rincontro si lasci nel fine quel, che doveva esser nel principio". Digressive passages were therefore not recommended, since Persico considered them time-wasting and superfluous. But some did survive in the first journalistic style we have examined, which was rooted in the very earliest, so to say, journalism: that contained in the letters sent by M. Caelius Rufus to Cicero. Cicero requested this kind of epistolary information after been appointed to the the governor of Cilicy and having been obliged to leave Rome. Rufus employed one man, Chrestus, who is probably the first known journalist in history. Persico recommends and encourages his readers to imitate this style, which was well-known from Cicero's and Pliny's letters.

This was a new and very different, though similar in purpose, genre from individual news or relations (see Claridge, 2000; Ettinghausen, 2015). News items to be published in a miscellaneous gazette had to be short, reduced to the "sostanza delle cose" ("substance of things"). Persico recommended a certain continuity of those news stories, at least from a formal point of view ("cosí per non variar nelle cose, com'anche per variar i principii delle lettere"), which was an incipient strategy in some of the Spanish gazettes exam- 
ined. That gave rise to periodicity as soon as communication networks were able to guarantee the news flow.

\section{Bibliographical references}

ADAM, J.-M. (1987). Le récit. Paris: Presses Universitaires de France.

ADAM, J.-M.; REVAZ, F. (1996). L'analyse des récits. Paris: Seuil.

Baena, F.; Fernández Travieso, C.; EsPejo, C.; Díaz Noci, J. (2014). "Codificación y representación cartográfica de noticias. Aplicación de las humanidades digitales al estudio del periodismo de la Edad Moderna”. El Profesional de la Información, 23(5), pp. 519-526. <http://dx.doi.org/10.3145/epi.2014.sep.09>

BAL, M. (2009). Narratology: Introduction to the Theory of Narrative. Toronto: University of Toronto Press.

BERNiNG, N. (2011). Narrative Means to Journalistic Ends. A Narratological Analysis of Selected Journalistic Reportages. Berlin: Springer.

BibER, D. (2009, 2012). "Corpus-Based and Corpus-driven Analyses of language Variation and Use". In: HeINE, B.; NARROG, H. (eds.). The Oxford Handbook of Linguistic Analysis. Oxford: Oxford University Press, pp. 1-34. <http://dx.doi.org/10.1093/oxfordhb/9780199544004.013.0008>

BoYs, J. J. E. (2012). London's News Press and the Thirty Years War. Woodbridge: Boydell and Brewer.

Broersma, M. (2007). Form and Style in Journalism. European Newspapers and the Representation of News 1880-2005. Leuven-Paris-Dudley, MA: Peeters.

BROWNLEES, N. (1999). Corantos and newsbooks: Language and discourse in the first English newspapers (1620-1641). Pisa: Edizioni ETS.

- (2008). "Telling news in mid-seventeenth century newsbooks". In: DOUTHWAITE, J.; PEZZINI, D. Words in action: diachronic and synchronic approaches to English discourse. Studies in honour of Ermanno Barisone. Genova: Edizioni culturali internazionali Genova, pp. 106-117.

- (2011a). "Tracing the historical development of news discourse in electronic corpora". In: MORENA, A. and NOWAK, Z. (eds.). Cultural Development, Artistic Creation \& Economic Growth. Florence: Ingorda, pp. 61-73.

- (2011b). The language of periodical news in seventeenth-century England. Newcastle upon Tyne: Cambridge Scholars Publishing.

- (2012). "Reporting the news in English and Italian diplomatic correspondence". In: Dossena, M.; del Lungo CAMiciotTI, G. (eds). Letter writing in late modern Europe. Amsterdam; Philadelphia: John Benjamins Publishing Company, pp. 121-137.

<http://dx.doi.org/10.1075/pbns.218.08bro>

- (2016). “'Newes also came by Letters': Functions and Features of Epistolary News in English News Publications of the Seventeenth Century". In: RAYMOND, J.; MOXHAM, N. (eds.). News Networks in Early Modern Europe. Leiden: Brill, pp. 394-419. $<$ http://dx.doi.org/10.1163/9789004277199>

CECCONI, E. (2009). "Comparing seventeenth-century news broadsides and occasional news pamphlets". In: JUCKER, A. H. (ed). Early Modern English News Discourse. Newspapers, Pamphlets and Scientific News Discourse. Amsterdam; Philadelphia: John Benjamins Publishing Company, pp. 137-157. 
CHARTIER, R.; EsPejO, C. (2012). La aparición del periodismo en Europa. Comunicación y propaganda en el Barroco. Madrid: Marcial Pons.

Claridge, C. (2000). "Pamphlets and Early Newspapers. Political Interaction vs News Reporting”. In: UNGERER, F. (ed). English media texts past and present. Language and textual structure. Amsterdam; Philadelphia: John Benjamins, pp. 25-43. $<$ http://dx.doi.org/10.1075/pbns.80.04cla>

CONBOY, M. (2007). The Language of the News. London: Routledge.

- (2010). The Language of Newspapers: Socio-historical Perspectives. London etc.: Bloomsbury.

DíAZ NOCI, J. (2008). “El Mediterráneo en guerra: relaciones y gacetas españolas sobre la guerra contra los turcos en la década de 1680". In: CIVIL, P.; CREMOUX, F.; SANZ HERMIDA, J.S. (coords.). España y el mundo mediterráneo a través de las Relaciones de Sucesos: Actas del IV Coloquio Internacional sobre Relaciones de Sucesos: (Paris, 23-25 de septiembre de 2004). Salamanca: Universidad de Salamanca, pp. 131-140.

- (2012). "Dissemination of News in the Spanish Baroque". Media History, 18(3-4), pp. 409-421. <http://dx.doi.org/10.1080/13688804.2012.721648>

— (2014). "Narratology of Online News". In: MESO, K.; LARRONDO, A.; TOUS-RoVIROSA, A. (cords.). Shaping the News Online. Covilha: LabCom, pp. 171-192.

- (2016). "The Iberian Position in European News Networks: A Methodological Approach”. In: RaYMOND, J.; MOXHAM, N. (eds.). News Networks in Early Modern Europe. Leiden: Brill, pp. 193-215. <http://dx.doi.org/10.1163/9789004277199_009>

ESPEJO, C. (2008). "El impresor sevillano Juan Gómez de Blas y los orígenes de la prensa periódica. La Gazeta Nueva de Sevilla (1661-1667)”. Zer, 13(25), pp. 243-267.

- (2011). "European Communication Networks in the Early Modern Age: A New Framework of Interpretation of the Birth of Journalism". Media History, 17(2), pp. 189-202.

<http://dx.doi.org/10.1080/13688804.2011.554730>

- (2015). "La circulación de las noticias en España a finales del siglo XVI. Relaciones de suceso de Rodrigo de Cabrera (1595-1600) sobre las guerras turcas". Estudios del mensaje periodistico, 21(1), pp. 89-103.

- (2016). "The Invention of the Gazette. Design Standardization in Spanish Newspapers, 1600-1650". Media History, 22, pp. 296-316.

<http://dx.doi.org/10.1080/13688804.2016.1149458>

EsPejo, C.; BAENA, F. (2015). "A Critique of Periodicity in Early Modern Journalism. The First Spanish Serial Gazette: Gazeta de Roma in Valencia (1618-1620)”, European Review, 23(3), pp. 341-353. <http://dx.doi.org/10.1017/S1062798715000046>

- (2016). "The Seville printer Juan de Cabrera (1623-1631): The Production of Serial News Pamphlets in 17th Century Spain”. Communication \& Society, 29(4), pp. 203-218.

<http://dx.doi.org/10.15581/003.29.4.sp.203-217>

ETtinghausen, H. (1993). La Guerra dels Segadors a través de la premsa de l'època. Barcelona: Curial.

- (2015). How the Press Began. The Pre-periodical Printed News in Early Modern Europe. A Coruña: SIELAE. 
EXPÓsITO, R. (2014). Informació i persuasió: en els orígens de la premsa catalana (c. 1500-1720). [PhD dissertation]. Girona: Universitat de Girona.

FACCHInetTI, R.; BROwnleEs, N.; BÖS, B.; FRIES, U. (2012). News as Changing Texts: Corpora, Methodologies and Analysis. Newcastle upon Tyne: Cambridge Scholars Publishing.

Fries, U.; SCHNEIDER, P. (2000). "ZEN: Preparing the Zurich English Newspaper Corpus”. In F. Ungerer (ed). English Media Texts Past and Present. Language and Textual Structure. Amsterdam; Philadelphia: John Benjamins, pp. 3-24. $<$ http://dx.doi.org/10.1075/pbns.80.03fri>

Groesen, M. van; Helmers, H. (2016). "Managing the News in Early Modern Europe, 1550-1800". Media History, pp. 1-6. <http://dx.doi.org/10.1080/13688804.2016.1234683>

GUINARD, J.-P. (1973). La presse espagnole de 1737 à 1791: formation et signification d'un genre. Paris: Centre de Recherches Hispaniques; Institut d'Études Hispaniques.

HAFFEMAYER, S. (1997). "Les gazettes de l'Ancien Régime: Approche quantitative pour l'analyse d'un “espace de l'information”. Histoire \& Mesure, 12(1-2), pp. 69-91. <http://dx.doi.org/10.3406/hism.1997.1486>

- (2002). L'information dans la France du XVIIe siècle : la gazette Renaudot de 1647 à 1663. Paris; Genève: H. Champion; Éditions Statkine.

INFELISE, M. (2005). "Los orígenes de las gacetas. Sistemas y prácticas de la información entre los siglos XVI y XVII". Manuscrits, 23, pp. 31-44.

- (2016). "The History of a Word: Gazzetta / Gazette". In J. RAYMOND, N. MOXHAM (eds.). News Networks in Early Modern Europe. Leiden: Brill, pp. 243-260. <http://dx.doi.org/10.1163/9789004277199_011>

HERMAN, D.; JAHn, M.; RYAN, M.-L. (2005). Routledge Encyclopaedia of Narrative Theory. London: Routledge.

KOOPMANS, J.W. (2016). "The Varying Lives and Layers of Mid-eighteenth-century News Reports". Media History, pp. 1-18. <http://dx.doi.org/10.1080/13688804.2016.1230009>

Nevalainen, T. (2002). "English Newsletters in the $17^{\text {th }}$ Century". In: FisCHER, A.; Tottie, G. and Lehmann, H. M. (eds.). Text Types and Corpora. Studies in Honour of Udo Fries. Tübingen: Gunter Narr, pp. 67-76.

Olivari, M. (2014). Avisos, pasquines y rumores. Madrid: Cátedra.

OlIVEIRA TEIXEIRA, P. (2013). Os sistemas jornalisticos europeus no século XVII e a génese do jornalismo - Uma comparação entre Portugal, Espanha e França. [PhD Dissertation]. Porto: Universidade Fernando Pessoa.

Persico, P. (1620). Del segretario. Venice: Damian Denaro.

Rospocher, M. (2012). Beyond the Public Sphere. Opinions, Publics, Spaces in Early Modern Europe. Bologna; Berlin: Il Mulino; Duncker \& Humblot.

SousA, J. (2009). Print Journalism in Early Modern Portugal. Porto: Media XXI.

SousA, J.; PInTO, M.; Silva, G. (2007). Génese do Jornalismo Lusófono e as Relaçóes de Manuel Severim de Faria (1626 - 1628). Porto: Universidade Fernando Pessoa. 
